М. В. КІНДРАЧУК ${ }^{1}$, І. А. ГУМЕНЮК ${ }^{1}$ А. О. ЮРЧУК ${ }^{1}$, Н. М. СТЕБЕЛЕЦЬКА В. В. ХАРЧЕНКО ${ }^{1}$, М. А. ГЛОВИН ${ }^{1}$, І. В. КОСТЕЦЬКИЙ

\author{
${ }^{1}$ Національний авіаційний університет, Київ \\ ${ }^{2}$ ВП НУБіП Украӥни «Бережсанський агротехнічний інститут»
}

\title{
БАГАТОКРИТЕРІАЛЬНА ОПТИМІЗАЦІЯ ТЕХНОЛОГІЧНОГО ПРОЦЕСУ ФОРМУВАННЯ ГРАДІЕНТНОГО ЗНОСОСТІЙКОГО ПОКРИТТЯ
}

Застосовуючи енергетичний підхід до очінювання зносостійкості поверхневих шарів за умов їх руйнування при терті розроблено технологічний процес формування градієнтного покриття з високою пропрацьованістю і зносостійкістю. Високі триботехнічні властивості покриття досягаються співвідношенням діаметра $i$ вмісту гранул наповнювача у верхньому підмарі, за рахунок чого забезпечується правило додатного градієнта механічних властивостей завдяки меншій твердості i підвищеній пластичності порівняно з нижснім підшаром. Проведений статистичний аналіз і досліджені регресійні моделі залежностей критеріїв оптимізаиії величини зносу і коефічієнта тертя від конструктивних, технологічних і експлуатаиійних факторів. В якості критеріїв оптимізації обрано інтенсивність зношування та коефічієнт тертя. Визначено провідні керовані і невзаємозамінні фактори, які найбільше впливають на прочес нанесення покриттів, а саме: діаметр гранул наповнювача, їх об'ємний вміст у покритті, повщина покриття, швидкість ковзання під час тертя та експлуатачійне навантаження в контакті трибоспряження. На основі иих результатів розроблено структуру та технологічний процес формування багатокомпонентного електролітичного покриття з високою припрацьовуваністю з додатнім градієнтом механічних властивостей. Завдяки використанню гранул карбіду вольфраму (твердішого та дисперснішого за карбід кремнію в матеріалі-прототипі) $і$ більш точному розподілу наповнювача в покритті вдалося одночасно підвищити його твердість і пластичність. Виконано триботехнічні дослідження градієнтних покриттів, якими підтверджено ӥх високі експлуатаиійні властивості. На основі триботехнічних випробувань покриттів отримано математичні моделі, що описують залежність величин зношування $і$ коефiиієнта тертя від конструктивних, технологічних та експлуатаційних факторів.

Ключові слова: градієнтне покриття, математична модель, багатокритеріальна оптимізація, інтенсивність зношування, коефіцієнт тертя

Вступ і постановка завдань дослідження. Відомо, що будь-який об'єкт трибосистеми, піддається структурній пристосовуваності. Утворені вторинні структури на робочих поверхнях спряження під час припрацювання в значній мірі визначають його подальшу зносостійкість, тобто зносостійкість і працездатність визначаються вихідною структурою матеріалу, а також станом контактних шарів, сформованих під час припрацювання (на початковому періоді експлуатації).

Було поставлено задачу створення способу нанесення композиційного електролітичного покриття 3 високою контактною втомною міцністю і зносостійкістю за рахунок формування його градієнтної структури: поверхневий шар зі складом та структурою з пониженим опором зсуву і глибинного підшару з більш крупними гранулами евтектичного сплаву.

Структура глибинного шару, де зосереджуються максимальні напруження тертя, забезпечує рівномірний розподіл навантаження в об'ємі покриття, чинить опір руйнуванню під дією тангенціально направлених сил тертя, демпфірує їх, тобто слугує міцною основою для поверхневого шару, підвищує його працезда- 
тність у екстремальних умовах тертя, виключаючи продавлювання, викришування та відшарування [1].

Тому, для створення оптимальних умов структурної пристосовуваності, тобто покращити його припрацьовуваність, а також підвищити зносостійкість розроблено технологічний процес нанесення захисного градієнтного покриття [2]. Завдяки градієнтним властивостям покриття можливо оптимізувати напружено деформований стан в системі «основа-покриття», підвищити зносостійкість та експлуатаційні і фізико-механічні властивості елементів трибоспряження.

При розробці технологічного процесу нанесення зносостійких покриттів потрібно вирішувати задачі щодо їх оптимізації. Ефективність прийнятих оптимізаційних рішень залежить від правильності вибору критеріїв, за якими буде оцінюватися працездатність сформованого зносостійкого поверхневого шару у заданих умовах експлуатації.

Вибір критеріїв оптимізації, керованих факторів та побудова плану експерименту. Критерії оптимізації в роботі обиралися з урахуванням наступного комплексу вимог $[3,4]$ :

- простий, зрозумілий фізичний зміст критерію та достатньо повне характеризування ним об'єкту або процесу, що досліджується;

- відповідність кожному значенню незалежних змінних одного (із точністю до випадкової помилки) значення відгуку;

- відтворюваність критерію, тобто збігання (з точністю до помилки експерименту) отриманих його значень при повторенні дослідів у номінально однакових умовах;

- вимірюваність значень критерію при будь-якій комбінації обраних рівнів факторів; ефективність критерію як з точки зору досягнення мети, так і у статистичному відношення.

3 огляду на те, що основною задачею дослідження є підвищення триботехнічних властивостей зміцнених деталей, у якості критеріїв оптимізації обиралися параметри, які можуть найбільш вичерпно та якісно охарактеризувати саме ці властивості матеріалів.

Зношування - це процес руйнування та відділення матеріалу з поверхні твердого тіла та (або) накопичення його залишкової деформації при терті, який проявляється у поступовій зміні розмірів та (або) форми тіла [5]. Знос - результат зношування, який визначається у встановлених одиницях (об'єму, маси, довжини тощо).

При вивченні процесу тертя виникає необхідність у розгляданні самих різноманітних взаємодій поверхонь: підйому по мікронерівностях абсолютно твердого тіла, пружного та пластичного деформування мікронерівностей, подолання ними міжатомної взаємодії, схоплення металів, утворення різного типу плівок тощо. Авторами [6] показано, що кількісною оцінкою взаємодії поверхонь у всіх випадках є коефіцієнт пропорційності між тангенціальною реакцією та нормальним навантаженням - коефіцієнт тертя. Значення саме цього коефіцієнту є одним 3 критеріїв, за яким проводять класифікацію тертя за видами, адже він, аналогічно інтенсивності зношування, залежить як від фізико-механічних властивостей контактуючих матеріалів, так і від умов тертя - питомого навантаження, швидкості ковзання, мастильного середовища тощо. Не дивлячись на те, що коефіцієнт тертя є функціонально пов'язаним із зносостійкістю, самостійно він не розкриває всіх часткових особливостей механізму зношування пар тертя в різних умовах мащення [7]. 
Отже, у роботі в якості критеріїв оптимізації зміцнених поверхневих шарів було обрано інтенсивність зношування ( $\left.\mathrm{Y}_{1}\right)$ та коефіцієнт тертя $\left(\mathrm{Y}_{2}\right)$ (табл. 1) [8].

Табличя 1

\section{Мета та обмеження критеріїв оптимізації}

\begin{tabular}{|c|c|c|c|c|}
\hline № & Назва критерію оптимізації & Мета & Позначення & Обмеження \\
\hline 1 & $\begin{array}{c}\text { Інтенсивність зношування } \\
\left(\mathrm{M \Gamma} / \mathrm{cm}^{2} \text { за } 10^{3} \mathrm{M}\right)\end{array}$ & МIHIMУМ & $Y_{1}$ & - \\
\hline 2 & Коефіцієнт тертя & МIHIMУМ & $\mathrm{Y}_{2}$ & - \\
\hline
\end{tabular}

Важливою вимогою, що висувається до керованих факторів $є$ відсутність їхньої взаємозамінності. Крім цього, фактори повинні відповідати наступним вимогам:

- бути керованими;

- не повинні залежати від інших змінних;

- сукупність обраних незалежних змінних повинна відповідати вимогам сумісності;

- інтервал зміни кожного фактору не повинен бути малим, одночасно, він не повинен бути дуже широким;

- рівні варіювання факторів повинні обиратися з урахуванням апріорної інформації щодо характеру впливу на відгук кожної змінної, точності підтримки рівня, здатності контрольно-вимірювальної апаратури, методів реєстрації, виду залежності відгуку від даної змінної; незалежні змінні повинні бути однозначними;

- вибір факторів повинен бути досить повним; точність фіксації факторів повинна бути високою (мінімальна різниця між значеннями сусідніх рівнів варіювання змінних повинна бути, принаймні, на порядок вище точності установки даного параметра).

При виборі керованих факторів до вивчення процесу підходили комплексно, тобто враховувався вплив конструктивних, технологічних та експлуатаційних факторів. Використовуючи методи експертної оцінки [9-11] i, зробивши серію відсіюючих експериментів, було отримано середній апріорний ранжируваний ряд факторів, які впливають на технологічний процес нанесення композиційних електролітичних покриттів (КЕП) (рис. 1).

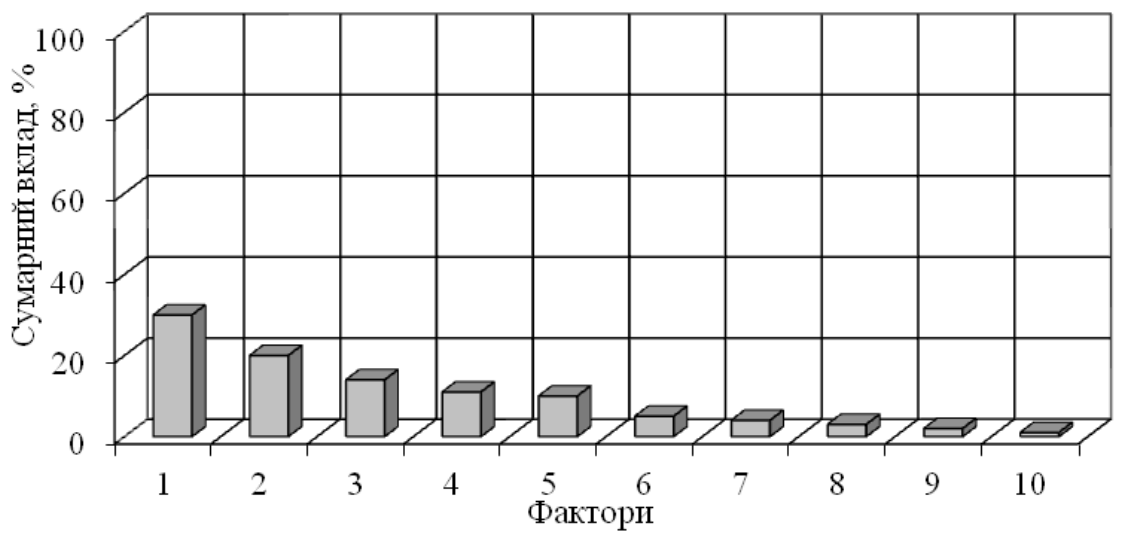

Рис. 1. Ранжируваний ряд конструктивних, технологічних та експлуатаційних факторів: 1 - діаметр гранул зовнішнього покриття ; 2 - вміст гранул; 3- товщина зовнішнього покриття; 4 - швидкість ковзання; 5 - експлуатаційне навантаження; 6 - густина катодного струму; 7 - температура формування покриття; 8- діаметр гранул нижнього покриття; 9 - товщина нижнього покриття; 10 - діаметр гранул проміжного покриття. 
Для моделювання процесу нанесення градієнтних покриттів на основі аналізу проведеного ранжирування було визначено групу факторів, що більше за всіх впливають на величину критеріїв оптимізації, та встановлено рівні їх варіювання. Тому в матрицю планування, як керовані фактори, були внесені: діаметр гранул $\left(\mathrm{X}_{1}\right)$, вміст гранул $\left(\mathrm{X}_{2}\right)$, товщина покриття $\left(\mathrm{X}_{3}\right)$, швидкість ковзання $\left(\mathrm{X}_{4}\right)$ та експлуатаційне навантаження $\left(\mathrm{X}_{5}\right)$ в умовах тертя (табл. 2$)$.

Табличя 2

Фактори та рівні їх варіювання

\begin{tabular}{|c|l|c|c|}
\hline № & \multicolumn{1}{|c|}{ Фактори } & Позначення & Рівні варіювання \\
\hline 1 & Діаметр гранул (мкм) & $\mathrm{X}_{1}$ & $0,1 \ldots 30$ \\
\hline 2 & Вміст гранул (\%) & $\mathrm{X}_{2}$ & $7 \ldots 28$ \\
\hline 3 & Товщина покриття (мкм) & $\mathrm{X}_{3}$ & $1 \ldots 20$ \\
\hline 4 & Швидкість ковзання (м/с) & $\mathrm{X}_{4}$ & $0,1 \ldots 0,5$ \\
\hline 5 & Навантаження (МПа) & $\mathrm{X}_{5}$ & $1 \ldots 5$ \\
\hline
\end{tabular}

Використовуючи фактори та значення рівнів їх варіювання для вирішення поставленої задачі, у роботі згенеровано план експерименту в кодованих значеннях, який представлений у табл. 3 у вигляді робочої матриці.

Таблиия 3

План експерименту в кодованих значеннях

\begin{tabular}{|l|c|c|c|c|c|}
\hline № & $\mathrm{X}_{1}$ & $\mathrm{X}_{2}$ & $\mathrm{X}_{3}$ & $\mathrm{X}_{4}$ & $\mathrm{X}_{5}$ \\
\hline 1 & 0,5 & 0,5 & 0,5 & 0,5 & 0,5 \\
\hline 2 & 0,25 & 0,75 & 0,25 & 0,75 & 0,25 \\
\hline 3 & 0,75 & 0,25 & 0,75 & 0,25 & 0,75 \\
\hline 4 & 0,125 & 0,625 & 0,875 & 0,875 & 0,625 \\
\hline 5 & 0,625 & 0,125 & 0,375 & 0,375 & 0,125 \\
\hline 6 & 0,375 & 0,375 & 0,625 & 0,125 & 0,875 \\
\hline 7 & 0,875 & 0,875 & 0,125 & 0,625 & 0,375 \\
\hline 8 & 0,0625 & 0,9375 & 0,6875 & 0,3125 & 0,1875 \\
\hline 9 & 0,5625 & 0,4375 & 0,1875 & 0,8125 & 0,6875 \\
\hline 10 & 0,3125 & 0,1875 & 0,9375 & 0,5625 & 0,4375 \\
\hline 11 & 0,8125 & 0,6875 & 0,4375 & 0,0625 & 0,9375 \\
\hline 12 & 0,1875 & 0,3125 & 0,3125 & 0,6875 & 0,5625 \\
\hline 13 & 0,6875 & 0,8125 & 0,8125 & 0,1875 & 0,0625 \\
\hline 14 & 0,4375 & 0,5625 & 0,0625 & 0,4375 & 0,8125 \\
\hline 15 & 0,9375 & 0,0625 & 0,5625 & 0,9375 & 0,3125 \\
\hline 16 & 0,03125 & 0,53125 & 0,40625 & 0,21875 & 0,46875 \\
\hline
\end{tabular}

Проведено перехід від кодованих значень до натуральних, що значно спрощує реалізацію плану експерименту (табл. 4).

На основі одержаних результатів проводилось нанесення градієнтних зносостійких покриттів та їх експериментальні дослідження.

Технологічний процес формування зносостійкого градієнтного покриття. Поставлено задачу створення способу нанесення КЕП з високою припрацьовуваністю і зносостійкістю за рахунок формування його градієнтної структури: 
нижнього і верхнього шарів зі складом та структурою прототипу і зовнішньої частини верхнього шару з пониженим опором зсуву.

Табличя 4

\section{План експерименту в натуральних значеннях}

\begin{tabular}{|c|c|c|c|c|c|}
\hline № & $\mathrm{X}_{1}$ & $\mathrm{X}_{2}$ & $\mathrm{X}_{3}$ & $\mathrm{X}_{4}$ & $\mathrm{X}_{5}$ \\
\hline 1 & 15 & 17,5 & 10,5 & 0,3 & 3 \\
\hline 2 & 7 & 22,8 & 5,75 & 0,4 & 2 \\
\hline 3 & 22 & 12,3 & 15,25 & 0,2 & 4 \\
\hline 4 & 4 & 20,1 & 17,62 & 0,45 & 3,5 \\
\hline 5 & 19 & 9,6 & 8,13 & 0,25 & 1,5 \\
\hline 6 & 11 & 14,9 & 12,88 & 0,15 & 4,5 \\
\hline 7 & 26 & 25,5 & 3,38 & 0,35 & 2,5 \\
\hline 8 & 2 & 26,7 & 14,06 & 0,23 & 1,75 \\
\hline 9 & 17 & 16,2 & 4,56 & 0,43 & 3,75 \\
\hline 10 & 9 & 10,9 & 18,81 & 0,33 & 2,75 \\
\hline 11 & 24 & 21,4 & 9,31 & 0,13 & 4,75 \\
\hline 12 & 6 & 13,6 & 6,94 & 0,38 & 3,25 \\
\hline 13 & 20 & 24,1 & 16,44 & 0,18 & 1,25 \\
\hline 14 & 13 & 18,9 & 2,19 & 0,28 & 4,25 \\
\hline 15 & 28 & 8,3 & 11,69 & 0,48 & 2,25 \\
\hline 16 & 1 & 18,2 & 8,72 & 0,19 & 2,88 \\
\hline
\end{tabular}

Поставлена задача вирішується тим, що формування нижнього і верхнього шарів зносостійкого електролітичного покриття проводять 3 електроліту, що містить наночастинки карбіду кремнію та гранули евтектичного сплаву заданого розміру і кількості, яке відрізняється тим, що зовнішня частина верхнього шару виконана у вигляді прошарку товщиною 10-15 мкм і містить наночастинки та гранули карбіду вольфраму (WC) діаметром 1-5 мкм при наступному співвідношенні компонентів електроліту, г/л:

хлорид нікелю (або заліза, або кобальту)

борна кислота

карбід вольфраму (гранули)

$20-30$

карбід вольфраму (наночастинки)

20-30.

У виробах з таким покриттям технічний результат досягається завдяки градієнтній структурі покриття. Адже відомо, що умовою існування зовнішнього тертя (задовільне припрацьоване і зносостійкість) є забезпечення правила градієнта зсувного опору, згідно з яким зсувний опір в зоні контакту твердих тіл повинен бути меншим, ніж на деякій глибині, тобто повинна дотримуватись $\frac{\delta \tau}{\delta z}>0$.

Співвідношення, склад і розмір компонентів у верхньому (зовнішньому) підшарі забезпечує менший зсувний опір завдяки підвищеній пластичності порівняно 3 нижнім основним підшаром. Більша дисперсність (1-3 мкм) гранул WC забезпечує пластичність, а їх вища мікротвердість (13 ГПа) порівняно з гранулами евтектичного сплаву-зносостійкість.

Зовнішній прошарок товщиною 10-15 мкм за час припрацювання утворює специфічні вторинні структури 3 високою стійкістю до температурно-силових впливів контактного фрикційного процесу і створює оптимальні умови для роботи 
основного матеріалу покриття, виключаючи його тріщиноутворення та крихке руйнування при терті [12]. На рис. 2 зображено будова градієнтного покриття.

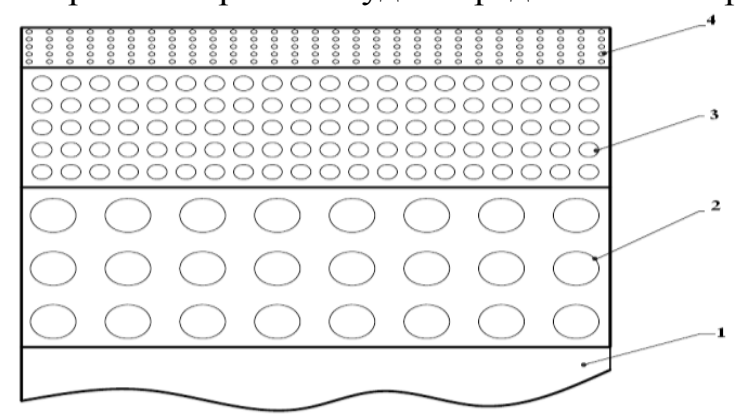

Рис. 2. Структура градієнтного покриття: 1 - стальна основа; 2 - нижній шар;

3 - нижній підшар верхнього шару; 4 - зовнішній підшар верхнього шару

Виріб з покриттям містить стальну основу 1 і нанесене на неї електролітичне покриття, що складається 3 нижнього 2 і верхнього шару 3 двома підшарами: нижнього 3 і верхнього зовнішнього 4.

Для одержання підшару даного складу градієнтного КЕП процес електрохімічного осадження гальванічного металу та порошків наповнювача, що знаходяться в електроліті, здійснювали на попередньо нанесене електролітичне покриття за найближчим аналогом на сталевих зразках (сплавах титану) зі стандартного хлористого електроліту нікелювання, що містить 320 кг/м ${ }^{3}$ хлористого ні-

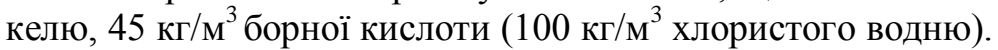

Процес проводили за температур від 40 до $60^{\circ} \mathrm{C}$, pH від $3 \div 4$ (або рН

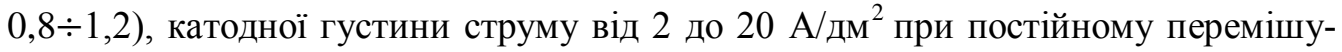
ванні електроліту стисненим повітрям. Вміст в електроліті наночастинок карбіду вольфраму задавали в межах від 20 до 30 кг/м³, а гранул карбіду вольфраму евтектичного сплаву від 20 до $30 \mathrm{\kappa} / \mathrm{m}^{3}$. Отримані покриття за даними хімічного аналізу містять від 19,2 до 25,4 мас. \% карбіду вольфраму.

У разі відхилення від оптимальних параметрів ведення процесу електролізу, складу електроліту в інтервалі концентрацій, що рекомендуються, густини струму та часу витримки в бік зменшення або збільшення, одержання композиційних покриттів заданого складу, структури й властивостей не забезпечується.

Триботехнічні властивості сформованого покриття. Випробування на тертя та знос за схемою односпрямованого тертя ковзання без мастила проводили на установці М-22 в наступних умовах: температура 273 К, навантаження 3 МПа, швидкість ковзання - 0,1 м/с, контртіло загартована сталь 45 HRC 43-48.

Підвищення зносостійкості градієнтного покриття у порівнянні 3 прототипом (див. табл. 5), обумовлено підвищенням твердості і пластичності поверхневого прошарку за рахунок більш твердого і дисперсного наповнювача карбіду вольфрама та мінімізацією напружень при терті.

Максимальну зносостійкість мають градієнтні покриття, що містять у зовнішній частині верхнього шару гранули WC діаметром 1-5 мкм. При зменшенні розміру гранул до 0,5 мкм зникає ефект макрозміцнення покриття.

Збільшення розміру гранул порошку WC зверх 5 мкм також знижує зносостійкість, що обумовлено зменшенням вмісту включень в підшарі, зниженням його механічних властивостей, зокрема пластичності. 


\section{Таблиияя 5}

Зносостійкість градієнтного КЕП, нанесеного на сталь 12Х18Н10Т, в залежності від розміру та вмісту гранул карбіду вольфраму в зовнішньому прошарку (P=3 МПа, V=0,1 м/с, T=293 К)

\begin{tabular}{|c|c|c|c|}
\hline Покриття & $\begin{array}{c}\text { Діаметр гранул } \\
\text { наповнювача, км }\end{array}$ & $\begin{array}{c}\text { Вміст гранул } \\
\text { наповнювача, мас.\% }\end{array}$ & $\begin{array}{c}\text { 3нос, } \mathrm{мг} / \mathrm{cm}^{2} \text { за } \\
10^{3} \mathrm{M}\end{array}$ \\
\hline Прототип: наповнювач SiC & 30 & 7,0 & 42,9 \\
\hline \multirow[t]{9}{*}{ Наповнювач WC } & 0,1 & 27,8 & 30,3 \\
\hline & 0,5 & 27,0 & 29,5 \\
\hline & 1,0 & 25,4 & 20,1 \\
\hline & 5,0 & 19,0 & 22,3 \\
\hline & 10,0 & 12,5 & 29,5 \\
\hline & 15 & 11,9 & 34,0 \\
\hline & 20 & 9,2 & 37,2 \\
\hline & 25 & 8,1 & 39,1 \\
\hline & 30 & 7,5 & 40,8 \\
\hline
\end{tabular}

Побудова математичних моделей за результатами триботехнічних досліджень. За результатами експерименту проведено статистичний аналіз та побудовано регресійні моделі залежності критерію оптимізації, який характеризує величину інтенсивності зношування $\left(\mathrm{Y}_{1}\right)$ та коефіцієнту тертя $\left(\mathrm{Y}_{2}\right)$ від конструктивних, технологічних та експлуатаційних факторів (табл. 2). Розрахунок моделей здійснювався за допомогою ППП ПРІАМ. В якості початкових даних використовувалися план експерименту в натуральних координатах (табл. 4) та результати експериментальних досліджень, що проведені двічі при одних і тих же умовах (табл. 6, табл. 7).

Інтенсивність зношування

\begin{tabular}{|c|c|c|}
\hline \multirow{2}{*}{$№$} & \multicolumn{2}{|c|}{$I, \mathrm{M} \Gamma / \mathrm{cm}^{2}$ за $10^{3} \mathrm{M}$} \\
\cline { 2 - 3 } & $\mathrm{Y}_{1,1}$ & $\mathrm{Y}_{1.2}$ \\
\hline 0 & 300 & 342 \\
\hline 1 & 27,4 & 29,7 \\
\hline 2 & 22,3 & 24,6 \\
\hline 3 & 34 & 36,3 \\
\hline 4 & 20,8 & 23,1 \\
\hline 5 & 29,5 & 31,8 \\
\hline 6 & 24,3 & 26,6 \\
\hline 7 & 39,1 & 41,4 \\
\hline 8 & 20,1 & 22,4 \\
\hline 9 & 29,3 & 31,6 \\
\hline 10 & 23,9 & 26,2 \\
\hline 11 & 37,2 & 39,5 \\
\hline 12 & 21,9 & 24,2 \\
\hline 13 & 30,3 & 32,3 \\
\hline 14 & 25,9 & 28,2 \\
\hline 15 & 40,8 & 43,1 \\
\hline 16 & 21,8 & 23.1 \\
\hline
\end{tabular}


Таблиия 7

Коефіціснт тертя

\begin{tabular}{|l|l|l|}
\hline \multirow{2}{*}{$№$} & \multicolumn{2}{|c|}{$\mu$} \\
\cline { 2 - 3 } & $\mathrm{Y}_{2.1}$ & $\mathrm{Y}_{2.2}$ \\
\hline 0 & 0,85 & 0,92 \\
\hline 1 & 0,48 & 0,57 \\
\hline 2 & 0,35 & 0,44 \\
\hline 3 & 0,6 & 0,69 \\
\hline 4 & 0,25 & 0,34 \\
\hline 5 & 0,55 & 0,64 \\
\hline 6 & 0,4 & 0,49 \\
\hline 7 & 0,68 & 0,77 \\
\hline 8 & 0,2 & 0,29 \\
\hline 9 & 0,5 & 0,59 \\
\hline 10 & 0,38 & 0,47 \\
\hline 11 & 0,65 & 0,74 \\
\hline 12 & 0,3 & 0,39 \\
\hline 13 & 0,58 & 0,67 \\
\hline 14 & 0,45 & 0,54 \\
\hline 15 & 0,7 & 0,79 \\
\hline 16 & 0,28 & 0,37 \\
\hline
\end{tabular}

Після обробки результатів експерименту отримано математичні моделі, що описують залежність величини зносу і коефіцієнта тертя від конструктивних, технологічних та експлуатаційних факторів.

$$
\begin{aligned}
& \mathrm{Y}_{1}=27,4683+10,2644 \mathrm{x}_{1}-9,64441 \mathrm{x}_{1} \mathrm{x}_{2}^{2} \mathrm{x}_{5}{ }^{2}-2,37748 \mathrm{x}_{3} \mathrm{x}_{4}{ }^{2} \mathrm{x}_{5} \\
& \mathrm{Y}_{2}=0,455106+0,237014 \mathrm{x}_{1}-0,0653093 \mathrm{x}_{1} \mathrm{x}_{4} \mathrm{x}_{5}^{2}+0,0572851 \mathrm{x}_{2}{ }^{2} \mathrm{x}_{3} \mathrm{x}_{5}
\end{aligned}
$$

де $\mathrm{Y}_{1}$ - математична модель в кодованих значеннях для інтенсивності зношування, $\mathrm{Y}_{2}$ - математична модель в кодованих значеннях для коефіцієнта тертя.

Отримані залежності, перевірені на адекватність, відтворюваність і інформативність результатів за критеріями математичної статистики (1). Результати статистичного аналізу представлені в табл. 8 та 9.

Результати повторних досліджень, що проведені в однакових умовах, перевірялися на статистичну відтворюваність за $\mathrm{G}$ - критерієм Кохрена. Для всіх регресійних залежностей $\mathrm{G}_{\text {розр }}<\mathrm{G}_{\text {табл }}$ при $\alpha=0,05$. Тому, ступінь розсіювання результатів за рядками матриці планування однакова, а результати відтворені.

Перевірка гіпотези на адекватність отриманих моделей результатів експерименту проводилася з використанням F - критерію Фішера. Для одержання мо-

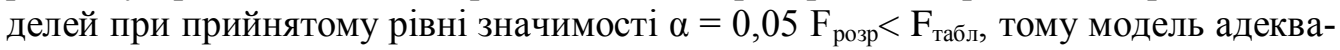
тно відображає результат експерименту.

Для визначених факторів проведено графічне дослідження їх впливу на критерії оптимізації, що характеризує інтенсивність зношення та коефіцієнт тертя градієнтного покриття (рис. 3 - для $\mathrm{Y}_{1}$, рис. 4 - для $\mathrm{Y}_{2}$ ).

Таким чином, у результаті проведеної з використанням одержаних математичних моделей багатокритеріальної (компроміс за Парето) оптимізації, було знайдено найоптимальніше поєднання рівнів конструктивних та технологічних 
факторів, що впливають на критерії оптимізації: діаметр гранул $\left(\mathrm{X}_{1}\right)-2$ мкм, вміст гранул $\left(\mathrm{X}_{2}\right)-26,7 \%$, товщина покриття $\left(\mathrm{X}_{3}\right)-14,6$ мкм.

Таблиця 8

Статистичні характеристики моделі інтенсивності зношування

\begin{tabular}{|l|l|}
\hline \multirow{2}{*}{ Параметри статистичного аналізу } & Значення параметрів для моделей \\
\cline { 2 - 2 } & \multicolumn{1}{|c|}{ Аналіз адекватності моделі } \\
\hline \multicolumn{1}{|c|}{ Залишкова дисперсія } & 0,392752 \\
\hline Дисперсія відтворюваності & 1,40187 \\
\hline Розрахункове значення F-критерію & 114,501 \\
\hline $\begin{array}{l}\text { Рівень значимості F-критерію для адек- } \\
\text { ватності для ступенів свободи. }\end{array}$ & $\begin{array}{l}0,05 \\
\mathrm{~V}_{1}=3, \mathrm{~V}_{2}=12\end{array}$ \\
\hline $\begin{array}{l}\text { Табличне значення F-критерію для аде- } \\
\text { кватності }\end{array}$ & 3,49029 \\
\hline Стандартна помилка оцінки. & 0,90812 \\
\hline $\begin{array}{l}\text { Стандартна помилка оцінки, скоректо- } \\
\text { вана з урахуванням ступенів свободи }\end{array}$ & 0,975477 \\
\hline \multicolumn{2}{|c|}{ Модель адекватна } \\
\hline
\end{tabular}

Табличя 9

Статистичні характеристики моделі коефіціснта тертя

\begin{tabular}{|l|l|}
\hline \multirow{2}{*}{ Параметри статистичного аналізу } & Значення параметрів для моделей \\
\cline { 2 - 2 } & \multicolumn{1}{|c|}{$\mathrm{Y}_{2}$} \\
\hline \multicolumn{2}{|c|}{ Аналіз адекватності моделі } \\
\hline Залишкова дисперсія & 0,000298804 \\
\hline Дисперсія відтворюваності & 0,0229687 \\
\hline Розрахункове значення F-критерію & 84,3573 \\
\hline $\begin{array}{l}\text { Рівень значимості F-критерію для аде- } \\
\text { кватності для ступенів свободи. }\end{array}$ & $\begin{array}{l}0,05 \\
\mathrm{~V}_{1}=3, \mathrm{~V}_{2}=12\end{array}$ \\
\hline $\begin{array}{l}\text { Табличне значення F-критерію для } \\
\text { адекватності }\end{array}$ & 3,49029 \\
\hline Стандартна помилка оцінки. & 0,0179749 \\
\hline $\begin{array}{l}\text { Стандартна помилка оцінки, скоректо- } \\
\text { вана з урахуванням ступенів свободи }\end{array}$ & 0,0193082 \\
\hline \multicolumn{2}{|c|}{ Модель адекватна } \\
\hline
\end{tabular}
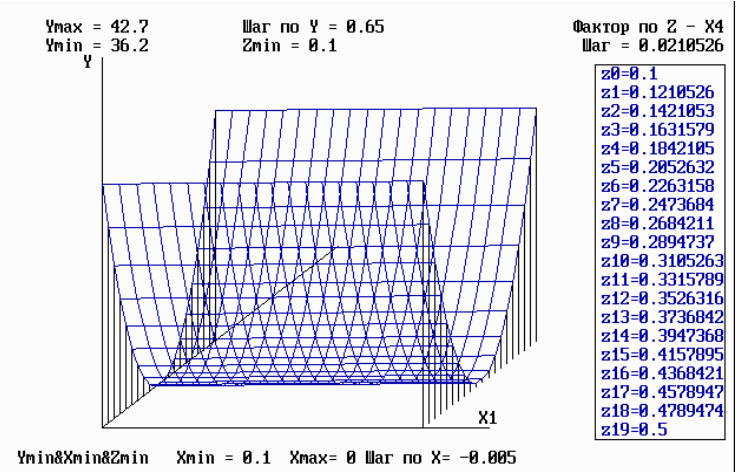

Рис. 3. Графік дослідження поверхні відгуку $\mathrm{Y}_{1}=\mathrm{f}\left(\mathrm{X}_{1}, \mathrm{X}_{4}\right)$ в тривимірному просторі при $\mathrm{X}_{2}=28$ $\% ; X_{3}=20$ мкм; $X_{5}=1$ МПа. 


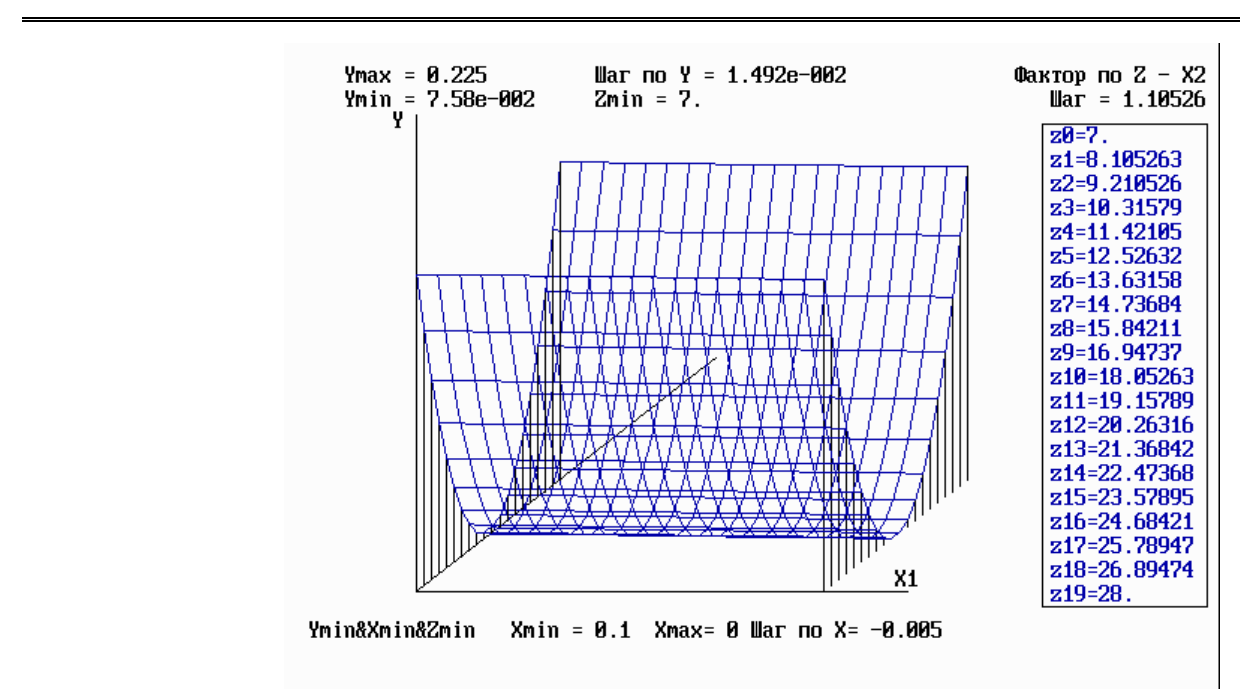

Рис. 4. Графік дослідження поверхні відгуку $\mathrm{Y}_{2}=\mathrm{f}\left(\mathrm{X}_{1}, \mathrm{X}_{2}\right)$ в тривимірному просторі при $\mathrm{X}_{3}=1$ мкм; $\mathrm{X}_{4}=0,5 \mathrm{~m} / \mathrm{c} ; \mathrm{X}_{5}=1 \mathrm{MПа}$.

Таким чином, у результаті проведеної з використанням одержаних математичних моделей багатокритеріальної (компроміс за Парето) оптимізації, було знайдено найоптимальніше поєднання рівнів конструктивних та технологічних факторів, що впливають на критерії оптимізації: діаметр гранул $\left(\mathrm{X}_{1}\right)-2$ мкм, вміст гранул $\left(\mathrm{X}_{2}\right)-26,7 \%$, товщина покриття $\left(\mathrm{X}_{3}\right)-14,6$ мкм.

Перевірка достовірності отриманих результатів проводилася шляхом нанесення зносостійкого градієнтного покриття за вказаними режимами, що отримані в результаті багатокритеріальної оптимізації й перевірки значень інтенсивності зношування (Y1) та коефіцієнту тертя (Y2) (критеріїв оптимізації). Відхилення складають $3 . .7 \%$, що свідчить про правильність отриманих результатів досліджень.

\section{Висновки:}

1. Розроблено технологічний процес формування градієнтного покриття 3 високою припрацьовуваністю і зносостійкістю, обумовленою забезпеченням виконання правила додатнього градієнта механічних властивостей.

2. Підвищення зносостійкості градієнтного покриття у порівнянні з найближчим аналогом, обумовлено підвищенням твердості і пластичності поверхневого прошарку за рахунок більш твердого і дисперсного наповнювача карбіду вольфрама та мінімізацією напружень при терті. Максимальну зносостійкість мають градієнтні покриття, що містять у зовнішній частині верхнього шару гранули WC діаметром 1-5 мкм. При зменшенні розміру гранул до 0,5 мкм зникає ефект макрозміцнення покриття. Збільшення розміру гранул порошку WC зверх 5 мкм також знижує зносостійкість, що обумовлено зменшенням вмісту включень в підшарі, зниженням його механічних властивостей, зокрема пластичності.

3. Проведено багатокритеріальну оптимізацію технологічного процесу формування зовнішнього підшару верхнього шару КЕП. Встановлено найоптимальніше поєднання рівнів конструктивних та технологічних факторів, що впливають на критерії оптимізації: діаметр гранул $\left(\mathrm{X}_{1}\right)-2$ мкм, вміст гранул $\left(\mathrm{X}_{2}\right)-26,7$ $\%$, товщина покриття $\left(\mathrm{X}_{3}\right)-14,6$ мкм.

4. Встановлено механізм зношування сформованого КЕП. Співвідношення, склад і розмір компонентів у верхньому (зовнішньому) підшарі забезпечує мен- 
ший зсувний опір завдяки підвищеній пластичності порівняно 3 нижнім основним підшаром. Більша дисперсність (1-3 мкм) гранул WC забезпечує пластичність, а їх вища мікротвердість (13 ГПа) порівняно з гранулами евтектичного сплаву-зносостійкість.

5. Зовнішній прошарок товщиною 10-15 мкм за час припрацювання утворює специфічні вторинні структури 3 високою стійкістю до температурно-силових впливів контактного фрикційного процесу і створює оптимальні умови для роботи основного матеріалу покриття, виключаючи його тріщиноутворення та крихке руйнування при терті.

\section{Список літератури}

1. Кіндрачук М.В. Роль локалізації напружень і деформацій в перехідній зоні «матриця-наповнювач» в кінетиці руйнування композиційних покриттів під час тертя / М.В. Кіндрачук, М.В. Лучка, В.Я. Лобурак, І.А. Гуменюк // Проблеми тертя та зношування, 2014, № 2 (63), c. 18-29.

2. Пат. 125389 України. Градієнтне покриття з високою припрацьовуваністю і зносостійкістю / Кіндрачук М. В., Мнацаканов Р. Г., Гуменюк І. А., Духота О. І., Харченко В. В.; № ; Заявл. 21.11.2017; опубл. 10.05.2018; Бюл. № 9, 4c.

3. Ю. А. Евдокимов, В. И. Колесников, А. И. Тетерин. Планирование и анализ эксперимента при решении задач трения и износа // М.: Наука, 1980, 228 с.

4. Лапач С. Н., Пасечник М. Ф., Чубенко А. В. Статистические методы в фармакологии и маркетинге фармацевтического рынка // К.: Укрспецмонтажпроект, 1999, 312 с.

5. Зносостійкість виробів. Тертя, зношування та мащення. Терміни та визначення : ДСТУ 2823-94. - [Чинний від 1994-10-31]. К. : Держстандарт України, 1994, 32 с. - (Національний стандарт України).

6. Костецкий Б. И., Носовский И. Г., Бершадский Л. И. Надежность и долговечность машин // К.: Техніка, 1975, 408 с.

7. Меделяев И.А. Влияние механических свойств пары "сталь-бронза" на коэффициент трения при граничной смазке / И.А. Меделяев // Вестник машиностроения. - 2006, № 2, c. 41-44.

8. Гуменюк I. А. Математичне моделювання формування зносостійких градієнтних покриттів на сталі 12X18H10T / I. А. Гуменюк // Тези доповідей Одинадцятої міжнародної конференції студентів, аспірантів та молодих вчених «Перспективні технології на основі новітніх фізико - матеріалознавчих досліджень та комп'ютерного конструювання матеріалів, 19-20 квітня 2018 р., Київ, Україна. - К. - С. 242-244.

9. Налимов В.В., Голикова Т.И. Логические основания планирования эксперимента. - М.: Наука, 1976. - 128 с.

10. Румшинский Л.З. Математическая обработка результатов эксперимента. - М.: Наука, 1971. - 192 с.

11. Федоров В.В. Теория оптимального эксперимента. // М.: Наука, 1971, 312 с.

12. Pashechko M. Gradient composite coating for working surfaces of braking devices / M. Pashechko, M. Kindachuk, I. Humeniuk. // Science and Technology Research Journal, 2018, №1, pp. 1-8.

Стаття надійшла до редакції 24.11.2020. 
M. V. KINDRACHUK, I. A. HUMENIUK, A. O. YURCHUK, H. M. STEBELETSKA, V. V. KHARCHENKO, M. A. GLOVIN, I. V. KOSTETSKYI

\section{MULTICRITERIA OPTIMIZATION OF TECHNOLOGICAL PROCESS OF DEPOSITION OF WEAR RESISTANT COATING}

Applying an energy approach to assessing wear resistance of surface layers under conditions of their destruction by friction, a technological process of generating a gradient coating with high workability and wear resistance has been developed. The statistical analysis is carried out and regression models of dependences of optimization criteria of wear rate and coefficient of friction on design, technological and operational factors are investigated. The wear intensity and friction coefficient were chosen as optimization criteria. Leading controlled and noninterchangeable factors that most influence the coating process are identified, namely: the diameter of the filler granules, their volume content in the coating, the thickness of the coating, the sliding speed during friction and the operating load in the triad junction. Based on these results, the structure and technological process of forming a multicomponent electrolytic coating with high workability with a positive gradient of mechanical properties were developed. Due to the use of tungsten carbide granules (harder and more dispersed than silicon carbide in the prototype material) and a more accurate distribution of the filler in the coating, it was possible to simultaneously increase its hardness and ductility. Due to the optimization of the ratio of the diameter and the content of the filler granules in the upper sublayer, the rule of the positive gradient of mechanical properties is provided. Thus, the upper layer is more malleable compared to the lower sublayer. Tribotechnical studies of gradient coatings were performed, which confirmed their high operational properties. The outer layer with a thickness of 10-15 $\mu \mathrm{m}$ creates optimal working conditions for the main part of the coating. Based on tribotechnical tests of coatings, mathematical models are obtained that describe the dependence of wear values and friction coefficient on structural, technological and operational factors.

Key words: gradient coating, mathematical model, multicriteria optimization, wear intensity, friction coefficient

\section{References}

1. Kindrachuk M.V. Rol lokalizatsii napruzhen i deformatsii $\mathrm{v}$ perekhidnii zoni «matrytsia-napovniuvach» v kinetytsi ruinuvannia kompozytsiinykh pok-ryttiv pid chas tertia / M.V. Kindrachuk, M.V. Luchka, V.Ia. Loburak, I.A. Humeniuk // Problemy tertia ta znoshuvannia, 2014, № 2 (63), c. 18-29.

2. Pat. 125389 Ukrainy. Hradiientne pokryttia z vysokoiu prypratsovuvanis-tiu i znosostiikistiu / Kindrachuk M. V., Mnatsakanov R. H., Humeniuk I. A., Dukhota O. I., Kharchenko V. V.; Zaiavl. 21.11.2017; opubl. 10.05.2018; Biul. № 9, 4s.

3. Evdokimov Iu. A. Planirovanie i analiz eksperimenta pri reshenii zadach treniia i iznosa / Iu. A. Evdokimov, V. I. Kolesnikov, A. I. Teterin // M.: Nauka, 1980, 228 s

4. Lapach S. N., Pasechnik M. F., CHubenko A. V. Statisticheskie metody v farmakologii i marketinge farmatsevticheskogo rynka // K.: Ukrspetsmontazhproekt, 1999, $312 \mathrm{~s}$.

5. Znosostiikist vyrobiv. Tertia, znoshuvannia ta mashchennia. Terminy ta vyznachennia : DSTU 2823-94. - [Chynnyi vid 1994-10-31]. - K. : Derzhstandart Ukrainy, 1994. - 32 s. (Natsionalnyi standart Ukrainy).

6. Kostetskii B. I., Nosovskii I. G., Bershadskii L. I. Nadezhnost i dolgovechnost mashin K.: Tekhnika, 1975, 408 s.

7. Medeliaev I. A. Vliianie mekhanicheskikh svoistv pary stal bronza na koeffitsient treniia pri granichnoi smazke / I. A. Medeliaev // Vestnik mashinostroeniia, 2006, 2, s. 41-44

8. Humeniuk I. A. Matematychne modeliuvannia formuvannia znosostiikykh hradiientnykh pokryttiv na stali 12Kh18N10T / I. A. Humeniuk // Tezy dopovidei Odynadtsiatoi mizhnarodnoi konferentsii studentiv, aspirantiv ta molodykh vche-nykh «Perspektyvni tekhnolohii na osnovi novitnikh fizyko - materialoznavchykh doslidzhen ta kompiuternoho konstruiuvannia materialiv, 19-20 kvitnia 2018 r., Kyiv, Ukraina, c. 242-244. 
9. Nalimov V. V., Golikova T. I. Logicheskie osnovaniia planirovaniia eksperimenta // M.: Nauka, 1976, $128 \mathrm{~s}$.

10. Rumshinskii L. Z. Matematicheskaia obrabotka rezultatov eksperimenta // M Nauka $1971192 \mathrm{~s}$

11. Fedorov V. V. Teoriia optimalnogo eksperimenta // M Nauka $1971312 \mathrm{~s}$

12. Pashechko M. Gradient composite coating for working surfaces of braking devices / M. Pashechko, M. Kindachuk, I. Humeniuk. // Science and Technology Research Journal, 2018, №1, p. 1-8.

Кіндрачук Мирослав Васильович - член-кореспондент НАН України, докт. техн. наук, професор, завідувач кафедри машинознавства, стандартизації та сертифікації Національного авіаційного університету, проспект Любомира Гузара, 1, м. Київ, Україна, 03058, +38(044)4067773, mail: nau12@ukr.net.

Гуменюк Ігор Анатолійович - канд. техн. наук, кафедра машинознавства, стандартизації та сертифікації Національного авіаційного університету, проспект Любомира Гузара,1, м. Київ, Україна, 03058, +38(044)4067773, mail: nau12@ukr.net.

Юрчук Аліна Олександрівна - канд. техн. наук, доцент кафедри комп'ютеризованих електротехнічних систем та технологій Національного авіаційного університету.

Стебелецька Наталія Миронівна - канд. техн. наук, доцент кафедри загальноінженерної підготовки ВП НУБіП України «Бережанський агротехнічний інститут» Тернопільська область, м. Бережани, вул. Академічна, 20, 47501, E-mail: kafedra.zd.bati@gmail.com.

Харченко Володимир Володимирович - аспірант, молодший науковий співробітник, завідувач лабораторії кафедри машинознавства, стандартизації та сертифікації Національного авіаційного університету, проспект Любомира Гузара,1, м. Київ, Україна, 03058, +38(044)4067773, mail: nau12@ukr.net.

Гловин Михайло Андрійович - студент Національного авіаційного університету, проспект Любомира Гузара,1, м. Київ, Україна, 03058.

Костецький Іван Володимирович - студент Національного авіаційного університету, проспект Любомира Гузара,1, м. Київ, Україна, 03058. 